\title{
The prevalence of anti-cyclic citrullinated peptide antibodies in juvenile idiopathic arthritis
}

\author{
Sandra H. Machado, ${ }^{1}$ Carlos A. von Mühlen, ${ }^{2}$ João C. T. Brenol, ${ }^{3}$ \\ Letícia Bisotto, ${ }^{4}$ Ricardo Machado Xavier ${ }^{5}$
}

\begin{abstract}
Objectives: To assess the presence of anti-cyclic citrullinated peptide antibodies in a cohort of patients with juvenile idiopathic arthritis.

Methods: Anti-cyclic citrullinated peptide antibodies was tested for with an enzyme linked immunoabsorbent assay (ELISA) in serum samples of patients from the Hospital de Clínicas de Porto Alegre, all less than 18 years old and with previous diagnosis for at least 6 months. IgMRF (rheumatoid factor) and antinuclear antibodies in Hep-2 cells were also assayed.

Results: Serum samples were analyzed from 45 patients. The presence of high levels of anti-cyclic citrullinated peptide antibodies was found in the serum of just one child (2\%), who presented sero-positive polyarthritis.

Conclusions: Anti-cyclic citrullinated peptide antibodies can be detected in children with juvenile idiopathic arthritis, but much less frequently than in adults with rheumatoid arthritis. It still remains to be determined whether anti-cyclic citrullinated peptide antibodies can identify a subset of juvenile idiopathic arthritis patients with the potential to progress to adult rheumatoid arthritis.
\end{abstract}

J Pediatr (Rio J). 2005;81(6):491-4: Juvenile idiopathic arthritis, anti-cyclic citrullinated peptide antibodies, diagnosis, immunology.

Juvenile idiopathic arthritis (JIA) is defined as a disease with onset before 16 years of age, primarily characterized by the presence of persistent arthritis in one or more joints, for at least six weeks, once other causes have been ruled out. 1,2 To date, JIA diagnosis is based on clinical history and physical examination, with supplementary methods being

1. MD. Pediatrician, Universidade Federal do Rio Grande do Sul (UFRGS), Porto Alegre, RS, Brazil.

2. Full professor, Medicine School, Pontifícia Universidade Católica do Rio Grande do Sul (PUCRS), Porto Alegre, RS, Brazil.

3. PhD. Chief of the Rheumatology Service, Hospital de Clínicas de Porto Alegre (HCPA). Professor, Department of Internal Medicine, UFRGS, Porto Alegre, RS, Brazil.

4. Nutritionist. MSc student, UFRGS, Porto Alegre, RS, Brazil.

5. PhD. Chief of the Clinical Pathology Service, HCPA. Professor, Department of Internal Medicine, UFRGS, Porto Alegre, RS, Brazil.

Manuscript received Jan 11 2005, accepted for publication Jun 152005.

Suggested citation: Machado SH, von Mühlen CA, Brenol JC, Bisotto L, Xavier RM. The prevalence of anti-cyclic citrullinated peptide antibodies in juvenile idiopathic arthritis. J Pediatr (Rio J). 2005;81:491-4 used primarily to rule out other diagnostic possibilities and comorbidity. There are no laboratory tests considered specific for confirming diagnosis. Biochemical laboratory tests and serological markers are useful aids to differential diagnosis, for classifying JIA subsets, assessing the extent of inflammation and determining prognosis and response to treatment. ${ }^{1,2}$

A positive serological diagnosis of JIA is restricted to patients with later onset polyarthritis who exhibit IgMRheumatoid Factor RF $(+)$, which is detected by nephelometry in 7 to $10 \%$ of cases. Antinuclear factors (ANA) were observed in 2 to $70 \%$ of the JIA populations studied, with the variability probably due to the different substrates used for measurement and the distinct subtypes of JIA. An elevated prevalence of ANA (between 65 and $85 \%$ ) has been observed with the JIA oligoarthritis subtype associated with uveitis ${ }^{1-3}$

A new autoantibody, anti-CCP (anti-cyclic citrullinated peptide) has been studied recently. Citrullin is an amino acid that is a post-translation modification of arginine residues. 
It is present in high concentrations in the fillagrin peptide chain. Regions that are rich in citrullin appear to become the target of antifillagrin antibodies, identified in rheumatoid arthritis, which gave rise to the development of a synthetic peptide rich in citrullin to produce a more stable and standardized enzyme immunoassay. ${ }^{4,5}$ Schellekens et al. ${ }^{6}$ observed that anti-CCP is highly specific (96-98\%) for rheumatoid arthritis (RA) in adults, with a sensitivity of $60 \%$. Some studies have shown the presence of anti-CCP in $60-75 \%$ of patients with confirmed with RA. ${ }^{7-9}$

The frequency of autoantibodies in adults has been reasonably well investigated, but their role in JIA has been little studied. Recent studies of the prevalence of anti-CCP in patients with JIA have observed that it can be detected in patients with polyarthritic onset and positive RF. 10-13

The objective of this study was to investigate the prevalence of anti-CCP antibodies in serum from patients with JIA, assessing its utility as a serological marker.

\section{Patients and methods}

Forty-five consecutive JIA patients were recruited from those being treated by the Rheumatology Department at our hospital from $01 / 06 / 2003$ to $31 / 12 / 2003$. The JIA diagnoses were performed based on criteria published by the International League of Associations for Rheumatology $(I L A R)^{14}$ for diagnosing the disease.

All patients under eighteen whose diagnoses had been confirmed for at least six months were included. Patients diagnosed with other autoimmune diseases, including superimposed syndromes, were excluded. Those legally responsible for the patients signed free and informed consent and the project was approved by Ethics Committee at the HCPA. ${ }^{15}$

Venous blood samples $(2-3 \mathrm{ml})$ were collected from all patients by peripheral venopuncture for routine laboratory workup. Serum samples were obtained by centrifuge and frozen at $-70^{\circ} \mathrm{C}$ until anti-CCP assay, which was performed for all samples at the same time. In addition to anti-CCP, the presence of antinuclear antibodies (indirect immunofluorescence with HEp-2 cells) and Rheumatoid factor IgM (nephelometry, BN2 System, Behring,USA) was also investigated.

Anti-CCP antibodies were determined using second generation ELISA (DIASTAT ${ }^{\mathrm{M}}$, Axis-Shield Diagnostics, Scotland, United Kingdom). The cutoff chosen for a positive result was a concentration above $10 \mathrm{U} / \mathrm{ml}$, as suggested by the manufacturer. The negative controls exhibited concentrations of less than $5 \mathrm{U} / \mathrm{ml}$.

Data from the statistical analysis is presented in the form of descriptive statistics and comparisons between values employ Student's $t$ test.

\section{Results}

The ages and clinical characteristics of the 45 patients studied are described in Table 1.
Table 1 - Demographic data

\begin{tabular}{lc}
\hline Age (mean) & 10 to $11 \mathrm{~m}( \pm 4$ to $1 \mathrm{~m})$ \\
Length of disease (mean) & 6 to $10 \mathrm{~m}( \pm 3$ to $10 \mathrm{~m})$ \\
Age at disease onset (mean) & 5 to $4 \mathrm{~m}( \pm 3$ to $1 \mathrm{~m})$ \\
Subtype & \\
Systemic & $7(16 \%)$ \\
Persistent oligoarthritis & $9(20 \%)$ \\
Extended oligoarthritis & $3(7 \%)$ \\
Polyarthritis RF $(+)$ & $5(11 \%)$ \\
Polyarthritis RF $(-)$ & $16(35 \%)$ \\
Psoriatic arthritis & $3(7 \%)$ \\
Enthesitis arthritis & $2(4 \%)$ \\
Total & $45(100 \%)$
\end{tabular}

Thirty-one of the 45 patients in this sample were female $(69 \%)$ and 14 were male (31\%). Their ages were within the range 3 to 17 years (mean 10 years, 11 months \pm 4 years, 1 month), and the mean age at onset of arthritis was 5 years, 4 months ( \pm 3 years 10 months). Forty-six percent of this sample presented with the polyarticular form of JIA.

Anti-CCP values for each patient are shown in Figure 1, broken down according to JIA subtype. With the exception of a single patient, all levels were below the cutoff for normality established by the laboratory.

Six children in the patient sample had reagent RF IgM (14\%): five of these presented polyarticular polyarticular disease and one oligoarticular extended disease.

We found just one case $(1 / 5,20 \%)$ of reagent anti-CCP in the subset of patients with seropositive polyarthritis (reagent FR IgM). None of the other subsets had reagent anti-CCP results. The difference in incidence of anti-CCP between JIA subtypes was not significant.

Additionally, just two patients exhibited reagent ANA, both with non-reagent RF IgM and anti-CCP and suffering from the oligoarticular form of JIA.

\section{Discussion}

Anti-CCP antibodies have been considered an important serological marker for diagnosing RA and also a possible marker of unfavorable prognosis. ${ }^{6-9}$

The present study has demonstrated, in contrast with what has been described with adult patients, that anti-CCP antibodies are rarely detectable in patients with JIA. AntiCCP was identified in just one case out of a series of 45 patients $(\cong 2 \%)$ with well-established diagnoses of JIA. Our results are in line with those reported by Avcin et al., 12 who observed anti-CCP positivity in two children out of 109 $(1.8 \%)$ suffering from JIA.

In contrast, van Rossum et al. ${ }^{10}$ recently presented the data from their study of 71 JIA patients, $15 \%$ of whom exhibited reagent anti-CCP, and $73 \%$ of these had reagent $\mathrm{RF}$. This difference in rates of anti-CCP frequency is probably secondary to differences in the populations studied and the assay techniques employed, in addition to the use of different cutoff points. The study undertaken by Rossum et 


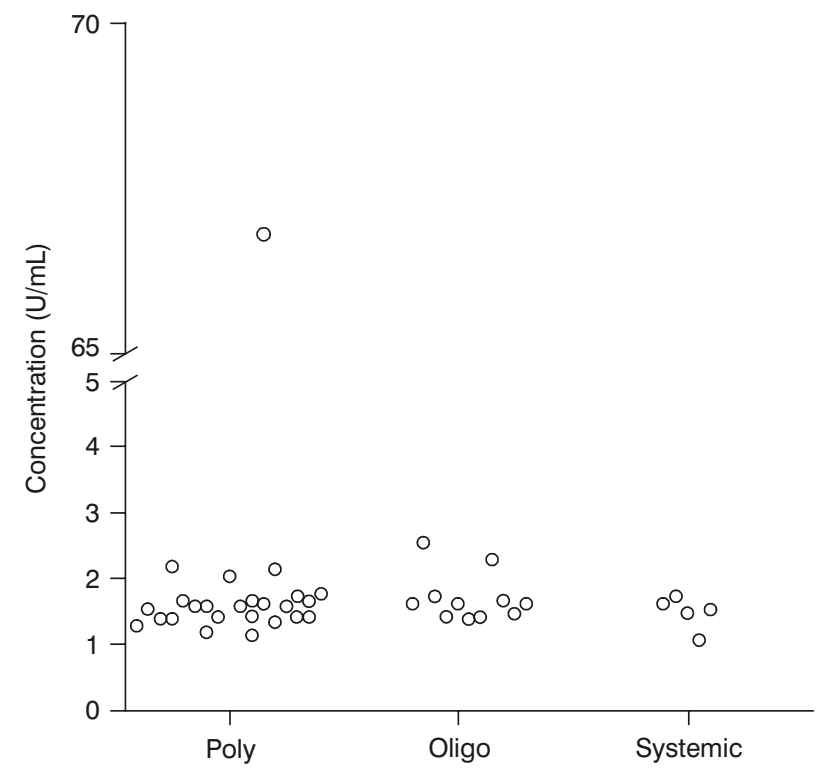

Figure 1 - Subgroups of juvenile idiopathic arthritis and concentrations of anti-cyclic citrullinated peptide antibodies

al., 10 employed a lower cutoff point than both our study and the one by Avcin et al.12 The choice of a higher cutoff is the result of opting to use a cutoff similar to that used when assaying anti-CCP in adults with AR, thus ensuring greater specificity.

Low et al. ${ }^{11}$ confirmed the presence of anti-CCP antibodies in children with JIA and correlated it with the presence of $R F$, suggesting a possible role for these antigenic peptides as JIA markers.

Recently, Lee $\&$ Schur $^{16}$ analyzed the frequency of antiCCP antibodies in a group of adult patients with diverse rheumatic diseases. In this group anti-CCP was positive in six out of 21 patients with JIA with disease onset more than 21 years previous, all had reagent FR and more severe forms of the disease.

In the present study, the one patient who was anti-CCP positive presented polyarticular disease and reagent RF and also later onset (13 years). This observation, together with findings by other authors, ${ }^{14-16}$ indicates the possibility that this auto-antibody may be a marker of JIA with the potential to progress to the typical form of adult AR.

In this study we observed that anti-CCP antibodies can be detected in a small number of patients with JIA, especially those who present the polyarticular and RF $(+)$ form of JIA that are recognized as being more severe and which become similar to rheumatoid arthritis of the adult as they progress. Prospective studies with larger patient samples will be necessary to verify whether these rare patients with reagent anti-CCP and RF constitute a differentiated subgroup of JIA, with progress and prognosis similar to those of adult RA patients.

\section{References}

1. Oliveira SK. Artrite idiopática juvenil. In: Oliveira SK, Azevedo EC, editors. Reumatologia Pediátrica. $1^{\text {a }}$ ed. Rio de Janeiro: REVINTER; 2001. p. 143-208.

2. Cassidy JT, Petty RE. Juvenile rheumatoid arthritis. In: Cassidy JT, Petty RE, editors.Textbook of Pediatric Rheumatology. 4th ed. Philadelphia: W. B. Saunders Co.; 2001. p. 214-221.

3. Nakamura RM. Progress in the use of biochemical and biological markers for evolution of rheumatoid arthritis. J Clin Lab Anal. 2000;14:305-13.

4. Serra CR, Rodrigues SH, Stanjnbok FR, Silva NP, AndradeLE. Antiperinuclear factor and antibodies to the stratum corneum of rat esophagus in juvenile idiopathic arthritis. J Pediatr. 1999;134:507-9.

5. van Venroij WJ, Pruijn GJ. Citrullination: a small change for protein with great consequences for rheumatoid arthritis. Arthritis Res. $2000 ; 2: 249-51$.

6. Schellekens GA, Visser $H$, de Jong $B A$, van den Hoogen $F H$, Hazes JM, Breedveld FC, et al. The diagnostic properties of rheumatoid arthritis antibodies recognizing a cyclic citrullinated peptide. Arthritis Rheum. 2000;43:155-63.

7. Bizzaro N, Mazzant G, Tanutti E, Violate D, Tozzoli R. Diagnostic accuracy of the anti-citrulline assay for rheumatoid arthritis. Clin Chemistry. 2001;47:1089-93.

8. Saraux A, Berthelot JM, Chales G, Le Henaff C, Mary JY, Thorel $V$, et al. Value of laboratory tests in early prediction rheumatoid arthritis. Arthritis Rheum. 2004;47:1089-93.

9. Gaalen FA, Linn-Rasker SP, Venrooij WJ, Jong BA. Autoantibodies to cyclic citrullinated peptides predict progression to rheumatoid arthritis in patients with undifferentiated arthritis - A prospective cohort study. Arthritis Rheum. 2004;50:709-15.

10. van Rossum $M$, van Soesbergen $R$, de Kort $S$, ten Cate $R$, Zwinderman $A H$, de Jong $B$, et al. Anti-cyclic citrullinated peptide (anti-CCP) antibodies in children with juvenile rheumatoid arthritis. J Rheumatol. 2003;30:825-8.

11. Low JM, Chauhan AK, Kietz DA, Daud U, Pepmueller PH, Moore TL. Determination of anti-cyclic citrullinated peptide antibodies in the sera of patients with juvenile idiopathic arthritis. J Rheumatol. 2004;31:1829-33.

12. Avcin T, Cimaz R, Falcini F, Zulian F, Martini G, Simonini G, et al. Prevalence and clinical significance of anti-cyclic citrullinated peptide antibodies in juvenile idiopathic arthritis. Ann Rheum. 2002;61:608-11. 
494

13. Moore TI, Chung AK, Pepmueller PH. Anti-ciclic citrulinated peptide antibodies in juvenile rheumatoid arthritis patients. Abstracts of 65 th Annual Scientific Meeting; Association of Rheumatology Health Professional 36th Annual Scientific Meeting; November 10-15, 2001; San Francisco, Califórnia. Arthritis Rheum. 2001;44:S338.

14. Petty RE, Southwood TR, Baum J, Bhettay E, Glass DN, Manners $P$, Maldonado-Cocco J, et al. Revision of the proposed classification criteria for juvenile idiopathic arthritis: Durban, 1997. J Rheumatol. 1998;25:1991-10.

15. Diretrizes e Normas Reguladoras de Pesquisa Envolvendo Seres Humanos- Resolução 1996 do Conselho Nacional de Saúde. Informe Epidemiológico do SUS, ano V, no 2, 1996, supl 03.
Prevalence of anti-CCP in juvenile idiopathic arthritis - Machado SH et alii

16. Lee DM, Schur PH. Clinical utility of the anti - CCP assay in patients with rheumatic diseases. Ann Rheum Dis. 2003;62: 870-4.

Correspondence:

Ricardo Machado Xavier

Rua Ramiro Barcelos, $23506^{\circ}$ andar, Rio Branco

Serviço de Reumatologia - HCPA

CEP 90035-903 - Porto Alegre, RS, Brazi

Tel.: +55 (51) 2101.8340

E-mail: rmaxavier@hcpa.ufrgs.br 